\title{
The Consumer Protection Act 68 of 2008 and Parol Evidence*
}

M Lombard*

\section{P.E.R}

Pioneer in peer-reviewed, open access online law publications

Author

Marianne Lombard

Affiliation

University of South Africa

Email lombam1@unisa.ac.za

Date Submission

2 February 2021

Date Revised

18 May 2021

Date Accepted

18 May 2021

Date published

5 July 2021

Editor Mr M Laubscher

How to cite this article

Lombard $\mathrm{M}$ "The Consumer

Protection Act 68 of 2008 and Parol Evidence" PER / PELJ 2021(24) DOI

http://dx.doi.org/10.17159/1727$3781 / 2021 / v 24 i 0 a 9486$

\section{Copyright}

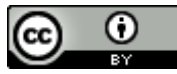

DOI

http://dx.doi.org/10.17159/17273781/2021/v24i0a9486

\begin{abstract}
The conflict between the objectives of the Consumer Protection Act 68 of 2008 - to protect consumers and ensure accessible and transparent redress - and the purpose of the parol evidence rule - to exclude extrinsic evidence and observe the maxim pact servanda sunt - is evident and forms the basis of this article. The purpose of consumer protection legislation is to balance the rights of consumers and suppliers, to protect the interests of consumers and to ensure efficient redress for consumers who have been wronged. The parol evidence rule, which is still in effect in South Africa, prohibits extrinsic evidence in a dispute to interpret a written agreement between parties to ensure certainty on the terms and conditions agreed to in writing. In practice, the parol evidence rule can disadvantage consumers who enter into standard-form contracts, as they normally are in an inferior bargaining position and cannot negotiate the individual terms and conditions of consumer agreements. It is obvious that the strict enforcement of the parol evidence rule in consumer agreements could lead to unjust results in consumer disputes. The provisions of the Consumer Protection Act 68 of 2008 are discussed to establish the extent of the limitation of the parol evidence rule therein. Then, the Consumer Rights Act, 2015 in the United Kingdom is considered to establish the tendency to limit the application of the rule in foreign consumer legislation, and to compare that to the position in South Africa. This article discusses whether the restriction or limitation of the parol evidence rule in the Consumer Protection Act is efficient in reaching the aims and objectives of the Act.
\end{abstract}

\section{Keywords}

Consumer; consumer protection; bargaining position; efficient redress; standard-form contract; parol evidence; Consumer Protection Act 68 of 2008; Consumer Rights Act, 2015. 


\section{Introduction}

The conflict between the objectives of the Consumer Protection Act 68 of 2008 (CPA) - to protect consumers and ensure accessible and transparent redress - and the purpose of the parol evidence rule - to exclude extrinsic evidence and observe the maxim pact servanda sunt - is evident and forms the basis of this article.

In general, the purpose of consumer protection legislation is to strike a balance between the rights and perceived vulnerabilities of the consumer on the one hand, and the rights and obligations of the supplier of goods or services on the other. ${ }^{1}$ The objectives of the CPA are to fulfil the rights of historically disadvantaged persons, to promote their full participation as consumers, and to protect the interests of consumers. It also seeks to ensure accessible, transparent and efficient redress for consumers who have been disadvantaged, abused or exploited in the marketplace, and to give effect to internationally recognised consumer rights. ${ }^{2}$

The parol evidence rule provides that no extrinsic evidence is allowed in a dispute to interpret a written agreement between parties. ${ }^{3}$ This is in line with the purpose of written agreements, which is to ensure certainty on the terms and conditions agreed to, ${ }^{4}$ following on the principle of freedom of contract ${ }^{5}$

This article is based on research conducted for my thesis, Regulation of Fixed-Term Contracts under the South African Consumer Protection Act 68 of 2008 (LLD-thesis University of South Africa 2020), under the supervision of Professor PN Stoop. I should like to thank him for his invaluable guidance and input. Any error that remains is mine.

** Marianne Lombard. BLC (UP) LLB (UP) LLM (Unisa) LLD (Unisa) Senior lecturer, Department of Mercantile Law, University of South Africa. Email: lombam1@unisa.ac.za.ORCID ID: https://orcid.org/0000-0002-4732-2918

1 Draft Green Paper on the Consumer Policy Framework (Gen N 1957 in GG 26774 of 9 September 2004) (the Green Paper) 4; s 3(1)(b) of the Consumer Protection Act 68 of 2008 (the CPA); Barnard Influence of the Consumer Protection Act 1.

2 Preamble of the CPA.

3 Du Bois et al Wille's Principles of South African Law 807; Van Jaarsveld and Oosthuizen Suid-Afrikaanse Handelsreg 111; Van Huyssteen, Lubbe and Reinecke Contract 167; Bradfield Christie's Law of Contract 226.

$4 \quad$ Du Bois et al Wille's Principles of South African Law 807; De Wet and Van Wyk SuidAfrikaanse Kontraktereg en Handelsreg 84; Van Jaarsveld and Oosthuizen SuidAfrikaanse Handelsreg 111; Hutchison and Pretorius Law of Contract 257-258; Lowrey v Steedman 1914 AD 532 543; Union Government v Vianini Ferro-Concrete Pipes (Pty) Ltd 1941 AD 43 47; Meyer v Merchants Trust Ltd 1942 AD 244 253; Harlin Properties v Los Angeles Hotel 19623 SA 143 (A); Venter v Birchholtz 1972 1 SA 276 (A) 282; Strydom v Coach Motors 19754 SA 838 (T); National Board (Pretoria) (Pty) Ltd v Estate Swanepoel 19753 SA 16 (A) 25; Reilly $v$ Seligson and Clare Ltd 19771 SA 626 (A) 637; Johnson v Leal 19803 SA 927 (A) 938, 943. Also see the case discussion by Cornelius 2009 TSAR 775.

5 Freedom of contract allows parties to decide, without interference, whether or not, with whom, and on what terms to contract. 
and the resultant common-law principle pacta servanda sunt, ${ }^{6}$ which aims to preserve the sanctity of agreements. The parol evidence rule potentially affects consumers adversely, as they are in a less favourable bargaining position when concluding a consumer agreement, ${ }^{7}$ as consumer agreements virtually always take the form of standard-form contracts which cannot be negotiated individually.

The supplier is usually in a better financial position than the consumer, has access to legal advice and enters into many standard-form contracts on a regular basis. The consumer is not always well-informed, especially in terms of the legal aspects and requirements of specific contracts and legislation, as well as the technical qualities or requirements of hi-tech electronic equipment. In addition, the consumer is usually in a less favourable financial position and does not necessarily have easy or affordable access to legal advice. When trying to prove his case in a dispute, the consumer would benefit from being able to refer to extrinsic evidence, such as the circumstances under which the agreement was entered into, the verbal communications between the consumer and the supplier, and the advertisements and promotional material of the supplier. The strict application of the parol evidence rule can lead to unjust results in disputes where the written document does not reflect the true intention of the parties. ${ }^{8}$ It can therefore impede efficient redress and transparent access to justice for consumers, thereby detracting from the objectives stated in the preamble and section 3 of the CPA.

$6 \quad$ Literally means agreements must be adhered to: Hiemstra and Gonin Drietalige Regswoordeboek 251; Printing and Numerical Registries Co v Sampson (1875) LR 19 Eq 462 465. This principle (pact servanda sunt) originated from the medieval canonists who adopted Roman law concepts to serve their own purposes; see Eiselen 1989 THRHR 521; for an analysis of the history and development of this principle, see Visser 1984 SALJ 641-655. Visser explains that this principle originated from Roman law and related to pacta or pacts, a term that was originally used in the sense of an agreement to redeem an obligation for liability in respect of a personal injury. A pact could obliterate an obligation, but it was not a cause of action. Grotius was instrumental in establishing the principle in Roman Dutch law and he regarded the maxim as the basis of positive law - see Visser 1984 SALJ 649651; Eiselen 1989 THRHR 521-522. Grotius accepted limitations on the principle amongst others in respect of employment agreements and usurious profits. See Eiselen 1989 THRHR 522.

7 South African courts and parliament have acknowledged inequality of bargaining power. Linstrom v Venter 19571 SA 125 (SWA) 127-128, 131; Aronstam Consumer Protection 23-24.

8 Van Jaarsveld and Oosthuizen Suid-Afrikaanse Handelsreg 111-112; Van Huyssteen, Lubbe and Reinecke Contract 172; Bekker 2014 PELJ 1142; Bradfield Christie's Law of Contract 384-390. There are strict requirements for the allegations in pleadings when a party wishes to make use of rectification. See Strydom $v$ Coach Motors 19754 SA 838 (T) 840-841. 
This article will provide a brief common-law background and state the content of the parol evidence rule as applied. Thereafter, the most relevant aspects of standard-form contracts, which are in everyday use and very important in consumer agreements under the CPA, will be highlighted. Then the treatment of the parol evidence rule in the CPA will be dealt with. In light of the provision of section 2((2)(a) and 2(2)(b) of the CPA that the court or Tribunal may consider appropriate foreign and international law and appropriate international conventions, declarations or protocols, the position under the Consumer Rights Act, 2015 (CRA) in the United Kingdom (UK) will be discussed to provide an objective view of the approach to parol evidence in foreign jurisdictions. ${ }^{9}$ Finally, the article will conclude with a discussion of the desirability of the inclusion or exclusion of parol evidence in consumer agreements under the CPA, and recommend improvements on the current position to ensure efficient redress and access to justice for consumers as envisaged by the legislature.

A lengthy discussion of the historical development of the parol evidence rule falls outside the scope of this article, as do the components, merits and correct interpretation of the rule in the South African common law of contract.

\section{Parol evidence under the common law}

At common law, most contracts are negotiated individually, according to the needs and wishes of the parties. Freedom of contract applies, and as a result, the maxim pacta servanda sunt is applied rigorously. ${ }^{10}$ Originating in English law, the parol evidence rule entails that when parties enter into a written contract, the original document with its written amendments, additions, or alterations, represents the only source of the terms and conditions of the agreement. ${ }^{11}$ In general, no extrinsic evidence may be led to alter the written agreement, as the purpose of requiring writing is to

$9 \quad$ European Union (EU) law has been incorporated into UK law and thereby enriched UK law with EU Directives, Guidance on EU Directives, and judgments from all countries within the EU. The EU is a European political and economic union established in 1993 when the Maastricht Treaty came into force. The EU has developed an internal EU market with standardised legislation. See Gabel 2020 https://www.britannica.com/topic/European-Union.

10 For instance, Wells v South African Alumenite Co1927 AD 69 (hereafter Alumenite) para 73. Aronstam Consumer Protection 182-184 criticises this harsh point of view by courts.

11 Du Bois et al Wille's Principles of South African Law 807; Van Jaarsveld and Oosthuizen Suid-Afrikaanse Handelsreg 111; Van Huyssteen, Lubbe and Reinecke Contract 167; Bradfield Christie's Law of Contract 226. 
ensure certainty regarding the terms and conditions of the agreement. ${ }^{12}$ Certain exceptions - eg memoranda, local commercial practice, invalid juristic acts, simulated contracts, collateral agreements, ${ }^{13}$ later amendments to agreements, suspensive conditions, and additional parties to the agreement - have been allowed by courts. ${ }^{14}$ The parol evidence rule also does not apply if its application would be to the detriment of bona fide third parties. ${ }^{15}$

In certain circumstances, courts have also permitted extrinsic evidence. ${ }^{16}$ The purpose of the parol evidence rule is to prevent uncertainty regarding the content of written agreements and to regulate the type and degree of evidence allowed in suitable circumstances. ${ }^{17}$ However, rectification of

12 Du Bois et al Wille's Principles of South African Law 807; De Wet and Van Wyk SuidAfrikaanse Kontraktereg en Handelsreg 84; Van Jaarsveld and Oosthuizen SuidAfrikaanse Handelsreg 111; Hutchison and Pretorius Law of Contract 257-258; Lowrey v Steedman 1914 AD 532 543; Union Government v Vianini Ferro-Concrete Pipes (Pty) Ltd 1941 AD 43 47; Meyer v Merchants Trust Ltd 1942 AD 244 253; Harlin Properties v Los Angeles Hotel 19623 SA 143 (A); Venter v Birchholtz 1972 1 SA 276 (A) 282; Strydom v Coach Motors 19754 SA 838 (T); National Board (Pretoria) (Pty) Ltd v Estate Swanepoel 19753 SA 16 (A) 25; Reilly v Seligson and Clare Ltd 19771 SA 626 (A) 637; Johnson v Leal 19803 SA 927 (A) 938, 943. Also see the case discussion by Cornelius 2009 TSAR 775. Bradfield Christie's Law of Contract 233; Du Plessis v Nel 19521 SA 513 (A) 519520, 529, 530 .

14 Bekker 2014 PELJ 1141-1142.

15 Van Huyssteen, Lubbe and Reinecke Contract 179.

16 Where the evidence will not modify or vary the terms of the agreement; when the dispute relates to the existence or validity of the agreement; to explain the terms used in the agreement; where collateral agreements are not inconsistent with the main agreement; in connection with an oral agreement after the written agreement was completed; when the parties want to establish what their respective rights and obligations are in terms of the agreement; where the evidence relates to a prior oral agreement that stipulates when the written agreement becomes effective. See Du Bois et al Wille's Principles of South African Law 807-809; Van Huyssteen, Lubbe and Reinecke Contract 170; Peter v Thomas (1908) EDC 140; Avis v Verseput 1943 AD 331.

17 Van Huyssteen, Lubbe and Reinecke Contract 167. The parol evidence rule is divided into two principles, namely the integration rule and the interpretation rule. The integration rule forms the essence of the parol evidence rule and regulates if, and to what degree, extrinsic evidence may be led to alter, amend or contradict the terms of the written agreement. Therefore, this rule speaks to the body or contents of the agreement and forms the first leg of the rule. The interpretation rule, on the other hand, guides as to the degree of extrinsic evidence and the circumstances when evidence may be brought to construe or interpret the words or terms already in the written agreement. Another rule, closely related to the parol evidence rule prohibits extrinsic evidence to alter or amend clear and unambiguous words and provisions in an agreement: see Cornelius 2009 TSAR 768; Van Huyssteen, Lubbe and Reinecke Contract 168. See the Delmas Milling Co Ltd v du Plessis 19553 SA 447 (A) judgment that was fundamental in the development of the parol evidence rule, as it set three rules for the admission of parol evidence. For a discussion of this judgment and the Coopers and Lybrand v Bryant 19953 SA 761 (A) judgment, see Cornelius 2009 TSAR 770-771 where he discusses these two judgments and their 
contracts is allowed to mitigate the harsh and unfair application of the parol evidence rule where the written agreement does not reflect the true intention of the parties because of a mutual error or mistake. ${ }^{18}$ The consequences of rectification are that the agreement after rectification reflects the true intention of the parties. ${ }^{19}$

Scholars, judges, and practitioners have for decades grappled with the interpretation, extent, application and components of the parol evidence rule. One school of thought advocates the abolition of the rule, while another proposes a virtually unlimited discretion for courts to hear any evidence in order to clarify and determine the exact intention of parties to an agreement. ${ }^{20}$

In the important case of KPMG Chartered Accountants (SA) v Securefin $L t d^{\circledR 1}$ the court held that the parol evidence rule still forms part of our law. It reiterated that practitioners do not often resort to the rule and courts often fail to enforce it. ${ }^{22}$ Harms AJ expressly stated that the interpretation of a written document is a legal matter as opposed to a factual one, and that therefore only the court can interpret the agreement ${ }^{23}$ and the normal rules of evidence apply. ${ }^{24}$

effect on the development of the rule. These terms and similar remedies obviously lead to confusion: Van Huyssteen, Lubbe and Reinecke Contract 168; Bekker 2013 Litnet Akademies 111-151; Bradfield Christie's Law of Contract 240.

18 Van Jaarsveld and Oosthuizen Suid-Afrikaanse Handelsreg 111-112; Van Huyssteen, Lubbe and Reinecke Contract 172; Bekker 2014 PELJ 1142; Bradfield Christie's Law of Contract 384-390. There are strict requirements for the allegations in pleadings when a party wishes to make use of rectification. See Strydom $v$ Coach Motors 19754 SA 838 (T) 840-841.

19 In Akasia Road Surfacing v Shoredits Holdings 20023 SA 346 (SCA) paras 16-17 the court held that vagueness in the agreement, although it affected the validity of the rectified agreement, did not prevent the defendant from applying to court to have the agreement rectified.

20 Bekker Ekstrinsieke Getuienis-Reël 530-532 proposes that courts should be able to consider any kind of evidence to decide disputes in pleadings. Courts should hold the wording and terminology in agreements in high regard - especially where the wording is clear and unambiguous. He concludes that courts should have an unlimited discretion to determine the true intention of parties to an agreement. Note that the CPA and agreements in terms of the CPA are interpreted in accordance with the provisions of $\mathrm{s} 4$ thereof.

21 KPMG Chartered Accountants (SA) v Securefin Ltd 20092 All SA 523 (SCA) (hereafter KPMG).

$22 \quad K P M G$ para 39.

23 KPMG para 39.

$24 K P M G$ para 39. In his discussion of the KPMG case, Cornelius observes contractual evidence can be divided into four categories: (i) evidence about the circumstances at the time of negotiation and conclusion of the agreement, which is admissible; (ii) evidence regarding what one of the parties detected at the time of conclusion of the agreement, which is generally not admissible, except to establish to what extent consensus exists; (iii) evidence on the parties' collective intention whilst negotiations 
Over the years, courts have become more liberal in their approach to and application of the parol evidence rule and have elected not to distinguish between surrounding circumstances and background circumstances. ${ }^{25}$ However, they remain justifiably cautious of allowing external evidence when interpreting the meaning of clauses in contracts, ${ }^{26}$ and the parol evidence rule still applies.

As standard-form contracts are used on a daily basis in commerce for most consumer agreements - cell phone agreements being a notable example they will be discussed briefly before moving on to the position of the parol evidence rule in the CPA.

\section{Standard-form contracts}

As commerce and industry developed, and because of mass production after the Industrial Revolution, the need arose for standardised mass contracts. ${ }^{27}$ The idealistic laissez-faire theory ${ }^{28}$ had been effective when parties negotiated contracts individually and were free to negotiate every term and condition of a contract, but when circumstances changed and most goods were mass-produced with small profit margins, it was essential for suppliers to operate in a manner both time- and cost effective. This led to the development of the standard-form contract, ${ }^{29}$ and can be seen as embodying the move from individualism to collectivism and led to the international introduction of consumer protection measures. ${ }^{30}$

The term standard-form contract can have three meanings. The first indicates that a specimen contract is used to draft the agreement and this

were taking place, which is admissible after KPMG; (iv) evidence of the background conditions that demonstrates the parties' respective intentions or quasi mutual consensus during negotiations and conclusion of the agreement, which is generally not allowed, although this could be relevant to establish if, and to what extent, there was consensus on the matter. See Cornelius 2009 TSAR 774-775. KPMG para 39; Bothma-Batho Transport (Edms) Bpk v S Bothma \& Seun Transport (Edms) Bpk 20142 SA 494 (SCA) para 12. KPMG para 39; Cornelius 2009 TSAR 775. For a brief history on the use of standard-form contracts see Aronstam Consumer Protection 16-18; Kessler 1943 Colum L Rev 631; Ahdieh 2006 Mich L Rev 1034. Laissez-faire literally means "allow to do" (Merriam Webster Date Unknown https://www.merriam-webster.com/dictionary/laissez-faire); figuratively it is interpreted as a philosophy that has as purpose to abstain from interfering with individual freedom of choice and actions. Gluck 1979 ICLQ73; Ahdieh 2006 Mich L Rev 1034; Aronstam Consumer Protection 20.

As a theory, collectivism opposes individualism and attempts to address the shortcomings identified by the individualist approach, by valuing the greater good of society as a collective above that of the individual. See Cockrell 1992 SALJ 40, 42; Stoop Concept "Fairness" in the Regulation of Contracts 28-29; Pretorius 2003 THRHR 639-642, 644-645. 
contract is then adapted according to the needs of the particular supplier. Secondly, it could refer to a contract that is generally and regularly used and is therefore accepted as a standard-form contract. The cell phone service agreement is an example of this so-called take-it-or-leave-it contract. Thirdly, it could mean a contract with statutorily prescribed terms. ${ }^{31}$

Standard-form contracts are usually printed documents drafted by the supplier who enters into numerous such contracts on a regular basis. ${ }^{32}$ The consumer is not in a position to negotiate the individual terms of the agreement and the only choice the consumer has is whether or not to sign. ${ }^{33}$ In addition, the consumer normally does not enter into many of these agreements and his only obligation is to pay the stipulated amounts.

Consumers accept that they cannot negotiate the terms and conditions in these agreements and that many of these terms are standard and provide for unlikely circumstances. ${ }^{34}$ The consumer normally enters into these agreements based on his or her perception of the reputation of the supplier and rarely reads the whole agreement. ${ }^{35}$ Consumers tend to look only at the dates, duration of the agreement and amounts payable before signing the agreement. ${ }^{36}$

The mere fact that a consumer signed a contract does not mean that the consumer has read and understood it. ${ }^{37}$ It should however be noted that just because a consumer could not, or did not negotiate the terms of the agreement does not necessarily imply that he or she suffers harm as a result thereof. ${ }^{38}$ Nevertheless, due to their inferior bargaining position and the contents of standard-form agreements, which are drafted by the supplier and protect his rights, consumers are at a distinct disadvantage when entering into standard-form agreements.

An important way of ensuring transparency and the fair treatment of consumers in standard-form agreements could be to exclude the parol evidence rule in consumer disputes, as this would allow the consumer to

\footnotetext{
$31 \quad$ Aronstam Consumer Protection 18-19.

32 The attributes of standard-form contracts were identified as such by Rakoff 1983 Harv L Rev 1177; also see Barnes 2007 Wash L Rev 234-235; an example is a cell phone service agreement.

Barnes 2007 Wash L Rev 237.

Barnes 2007 Wash L Rev 237.

Barnes 2007 Wash L Rev 237.

Barnes 2007 Wash L Rev 237.

Harland 1991 JILI 189.

This principle was stated clearly by Coetzee $\mathrm{J}$ in Western Bank Ltd $v$ Sparta Construction Co 19751 All SA 224 (W) 226.
} 
reveal all the relevant information and circumstances under which the agreement was concluded.

\section{Parol evidence under the CPA}

\subsection{Introduction and background}

The purpose of the CPA as set out in the preamble is that the Act should inter alia develop effective means of redress for consumers and give effect to internationally recognised consumer rights. However, the United Nations Consumer Guidelines ${ }^{39}$ do not deal with the use of the parol evidence rule. ${ }^{40}$ The Draft Green Paper on the Consumer Policy Framework ${ }^{41}$ (the Green Paper) had as its purpose to drive competitiveness, consumer confidence and business excellence. Although the Green Paper does not specifically address the parol evidence rule, two of its objectives could be linked to the possible exclusion of the parol evidence rule. The first is the objective to provide consumers with effective redress, ${ }^{42}$ and the second is to harmonise our consumer law regime with the best jurisdictions internationally. ${ }^{43}$ The Consumer Protection Bill ${ }^{44}$ does not expressly mention parol evidence and the sections relevant to parol evidence included in the CPA will be discussed hereafter.

South Africa is a constitutional democracy - and as such the Constitution of the Republic of South Africa, 1996 (the Constitution) is the supreme law as it specifically states that all conduct or law inconsistent with the Constitution

39 UNCTAD $2016 \quad$ https://unctad.org/en/PublicationsLibrary/ditccplpmisc 2016d1_en.pdf (United Nations Consumer Guidelines).

The only two clauses of the United Nations Consumer Guidelines potentially relevant to the application or the abolishment of the rule are the following:

"Clause 26 - Consumers should be protected from such contractual abuses as onesided standard contracts, exclusion of essential rights in contracts and unconscionable conditions of credit by sellers.

Clause 37: Member States should encourage the development of fair, effective, transparent and impartial mechanisms to address consumer complaints through administrative, judicial and alternative dispute resolution, including for cross-border cases. Member States should establish or maintain legal and/or administrative measures to enable consumers or as appropriate, relevant organizations to obtain redress through formal or informal procedures that are expeditious, fair, transparent, inexpensive and accessible. Such procedures should take particular account of the needs of vulnerable and disadvantaged consumers. Member States should provide consumers with access to remedies that do not impose a cost, delay or undue burden on the economic value at stake and at the same time do not impose excessive or undue burdens on society and businesses."

41 A final version of the Green Paper was never released.

42 Green Paper 13, 37-48.

43 Green Paper 13. In addition, the Green Paper 30 recognises the inequality in bargaining power that exists between consumers and suppliers.

44 Consumer Protection Bill [B19 2008] ( $3^{\text {rd }}$ draft). 
is invalid. ${ }^{45}$ Therefore, all legislation is also subject to the provisions of the Constitution $^{46}$ and the Constitutional Court's decisions are binding on all other courts. The Constitution does not shed light on the parol evidence rule, although section 34, dealing with the right of access to courts and stating that

everyone has the right to have any dispute resolved by application of the law decided in a fair public hearing before a court, where appropriate, another independent and impartial tribunal or forum

could perhaps be relevant. The words "fair public hearing" could potentially be developed under the common law by applying transformative constitutionalism. ${ }^{47}$ The parol evidence rule could thereby be limited or abolished in certain circumstances, enabling the fair public hearing intended in section 34 of the Constitution. Section 39 of the Constitution could also be relevant in that it promotes values that underlie an open and democratic society, such as fairness, transparency and efficient redress for consumers.

\subsection{Parol evidence under the CPA}

The purposes and policy of the CPA are provided for in section 3 and are generally aimed at creating an environment in which consumers are treated fairly, are not disadvantaged and are protected. ${ }^{48}$ Section $3(1)(b)$ in particular, provides for consumers who are disadvantaged for a number of reasons, such as low income, living in remote areas, particular vulnerability due to old age or other similar vulnerabilities, limited reading skills, visual impairments or limited language fluency. It is clearly essential that parol evidence be allowed in order to grant these disadvantaged consumers effective redress and access to justice. The possible relevance of section

Section 2 of the Constitution of the Republic of South Africa, 1996 (the Constitution).

46 See for instance, Everfresh Market Virginia (Pty) Ltd $v$ Shoprite Checkers (Pty) Ltd 20121 SA 25 (CC); Phumelela Gaming and Leisure Limited v Gründlingh 20068 BCLR 883 (CC).

47 Transformative constitutionalism means that when courts decide a dispute, the Constitution must be interpreted liberally to promote political and socio-economic change and reform. For general background on this topic see Moseneke 2009 Stell LR 3-13; Tladi 2002 De Jure 306-317; Langa 2006 Stell LR 351-360; Van der Walt 2005 TSAR 655-689; Van der Walt 2006 TSAR 1-31. Klare 1998 SAJHR 150-151 stresses that this interpretation should try to give effect to the hopes and ideals of the Constitution. See also Bhana Constitutionalising Contract Law 36-38, 241-242. In addition, it is clear that the CPA is legislation that aims to effect political and socioeconomic change - see Imperial Group (Pty) Ltd t/a Cargo Motors Klerksdorp v Dipico 2016 ZANCHC 1 (1 April 2016) where the court referred to the CPA as "a social justice piece of legislation" that has as purpose, inter alia, to protect consumers by ensuring that they have clear and unobstructed access to redress. The subsections relevant to this article are ss 3(1)(a), (c), (d) and (h) of the CPA. 
2(10) of the CPA, which provides that the consumer retains his commonlaw rights, should also be noted.

The CPA does not have an express provision on parol evidence. However, the following sections in the CPA could be interpreted to imply that courts or the Tribunal will have some freedom of discretion to relax the parol evidence rule:

- Section 2, which provides for the interpretation of the CPA, and section 2(1) which states that it must be interpreted to give effect to the purposes set out in section 3 .

- $\quad$ Section 3 which sets out the purpose and policy of the CPA. ${ }^{49}$ The subsection/s potentially relevant to parol evidence are section 3(1)(a), which aims to establish a legal framework that is fair, accessible, efficient, sustainable and responsible for the benefit of consumers generally. Section $3(1)(d)$ relates to the limitation of the parol evidence rule in section 52 . In addition, section $3(1)(h)$ states that the purpose of the Act is to provide for an accessible, consistent, harmonised,

$49 \quad 3(1)$ The purposes of this Act are to promote and advance the social and economic welfare of consumers in South Africa by-:

(a) establishing a legal framework for the achievement and maintenance of a consumer market that is fair, accessible, efficient, sustainable, and responsible for the benefit of consumers generally;

(b) reducing and ameliorating any disadvantages experienced in accessing any supply of goods or services by consumers-

(i) who are low-income persons or persons comprising low-income communities;

(ii) who live in remote, isolated or low density population areas or communities;

(iii) who are minors, seniors or other similarly vulnerable consumers; or

(iv) whose ability to read an comprehend any advertisement, agreement, mark, instruction, label, warning, notice or other visual representation is limited by reason of low literacy, vision impairment or limited fluency in the language in which the representation is produced, published or presented;

(c) promoting fair business practices;

(d) protecting consumer from -

(i) unconscionable, unfair unreasonable, unjust or otherwise improper trade practices; and

(ii) deceptive, misleading, unfair or fraudulent conduct;

(e) improving consumer awareness and information and encouraging responsible and informed consumer choice and behavior;

(f) promoting consumer confidence, empowerment, and the development of a culture of consumer responsibility, through individual and group education, vigilance, advocacy and activism;

(g) providing for a consistent, accessible and efficient system of consensua resolution of disputes arising from consumer transactions; and

(h) providing for an accessible, consistent, harmonised, effective and efficient system of redress for consumers." 
effective and efficient system of redress for consumers. Section $3(2)(a)^{50}$ also aims to ensure the realisation of the purposes of the Act. In addition, the National Consumer Commission is made responsible for taking reasonable and practical measures to promote the purposes of the Act ie, to protect and advance the interests of consumers, particularly the vulnerable consumers set out in section 3(1)(b). This implies that disputes arising from consumer transactions should be heard by means of an efficient system of redress. This could be read to imply that all reasonable and relevant evidence should be allowed to assist the consumer in proving his claim, thereby including parol evidence.

- $\quad$ Section $4(2)^{51}$ expressly instructs the Tribunal and courts to develop the common law as necessary to improve the enjoyment and realisation of consumer rights, and particularly those of vulnerable persons as envisaged in section 3(1)(b). The Tribunal and courts must also promote the spirit and purposes of the CPA, and finally, where there is ambiguity, the Tribunal or court must choose the meaning that benefits the rights of the consumer, particularly vulnerable consumers.

- $\quad$ Section $4(4)^{52}$ sets very strict rules for courts or Tribunals to interpret standard forms, contracts and other documents prepared by the

"3(2) To better ensure the realisation of the purposes of this Act, and the enjoyment of the consumer rights recognised or conferred by this Act, the Commission, in addition to its responsibilities set out elsewhere in this Act, is responsible to-

(a) take reasonable and practical measures to promote the purposes of this Act and to protect and advance the interests of all consumers, and in particular those consumers contemplated in subsection (1)(b)."

51 "4(2) In any matter brought before the Tribunal or a court in terms of this Act-

(a) the court must develop the common law as necessary to improve the realisation and enjoyment of consumer rights generally, and in particular by persons contemplated in section $3(1)(b)$; and

(b) the Tribunal or court, as the case may be, must-

(i) promote the spirit and purposes of this Act; and

(ii) make appropriate orders to give practical effect to the consumer's right of access to redress, including, but not limited to-

(aa) any order provided for in this Act; and

(bb) any innovative order that better advances, protects, promotes and assures the realisation by consumers of their rights in terms of this Act.

4(3) If any provision of this Act, read in its context, can reasonably be construed to have more than one meaning, the Tribunal or court must prefer the meaning that best promotes the spirit and purposes of this Act, and will best improve the realisation and enjoyment of consumer rights generally, and in particular by persons contemplated in section 3(1)(b)."

Van Eeden and Barnard Consumer Protection Law 512-513.

"4(4) To the extent consistent with advancing the purposes and policies of this Act, the Tribunal or court must interpret any standard form, contract or other document 
supplier, or on behalf of the supplier. These rules include provisions on the interpretation of ambiguity, ${ }^{53}$ which ambiguity should be interpreted in a reasonable way to benefit the consumer. Restrictions, limitations, exclusions or deprivations of consumers' rights in contracts must also be limited to the extent a reasonable person would normally expect. ${ }^{54}$ When interpreting these restrictions on the consumer's rights, the court or Tribunal should consider the content of the document, ${ }^{55}$ the way in which the documents were prepared and presented to the consumer, ${ }^{56}$ and the circumstances of the contract. ${ }^{57}$ It is not a general exclusion of the parol evidence rule from all consumer related disputes, but the effect of sections 4(4)(b)(ii and iii) is that the parol evidence rule be excluded for the purposes envisaged in the subsections.

The effect of the following sections is more direct and empowers courts and Tribunals to consider extrinsic evidence:

- $\quad$ Section 48(1)(a)(i), 48(1)(b), 48(2)(c), and 48(2)(d)(i) and (ii), provide for unfair, unreasonable and unjust contract terms, and therefore extrinsic evidence may be presented to court in the circumstances provided for in the section, in order to establish whether the terms of the agreement are unfair, unjust, or unreasonable. ${ }^{58}$

- $\quad$ Section 52 deals with the powers of courts to ensure fair and just conduct, terms and conditions. ${ }^{59}$ Subsection 2 of section 52 of the CPA

prepared or published by or on behalf of a supplier, or required by this Act to be produced by a supplier, to the benefit of the consumer-

(a) so that any ambiguity that allows for more than one reasonable interpretation of a part of such a document is resolved to the benefit of the consumer; and

(b) so that any restriction, limitation, exclusion or deprivation of a consumer's legal rights set out in such a document or notice is limited to the extent that a reasonable person would ordinarily contemplate or expect, having regard to-

(i) the content of the document;

(ii) the manner and form in which the document was prepared and presented; and

(iii) the circumstances of the transaction or agreement."

Section 4(4)(a) CPA.

Section 4(4)(b) CPA; Van Eeden and Barnard Consumer Protection Law 513.

Section 4(b)(i) CPA.

Section 4(b)(ii) CPA.

Section 4(4)(b)(iii) CPA.

Levenstein and Barnett 2010 Without Prejudice 30-31.

"52(1) If, in any proceedings before a court concerning a transaction or agreement between a supplier and consumer, a person alleges that-

(a) the supplier contravened section 40,41 or 48 ; and

(b) this Act does not otherwise provide a remedy sufficient to correct the relevant prohibited conduct, unfairness, injustice or unconscionability, the court, after 
provides that extrinsic evidence may be presented to court to establish: 60

○ whether the terms in the agreement are unconscionable, ${ }^{61}$

- where false, misleading or deceptive representations were made to the consumer, ${ }^{62}$ or

- where a price offered or supplied to the consumer is unfair, unreasonable or unjust, ${ }^{63}$ and

- where the supplier markets, negotiates or administers the contract or terms thereof in a way that is unfair, unjust or unreasonable. ${ }^{64}$

The matters courts can consider are set out in section 52(2), and these matters clearly restrict the parol evidence rule for the prescribed

considering the principles, purposes and provisions of this Act, and the matters set out in subsection (2), may make an order contemplated in subsection (3).

(2) In any matter contemplated in subsection (1), the court must consider-

(a) the fair value of the goods or services in question;

(b) the nature of the parties to that transaction or agreement, their relationship to each other and their relative capacity, education, experience, sophistication and bargaining position;

(c) those circumstances of the transaction or agreement that existed or were reasonably foreseeable at the time that the conduct or transaction occurred or agreement was made, irrespective of whether this Act was in force at that time;

(d) the conduct of the supplier and the consumer, respectively;

(e) whether there was any negotiation between the supplier and the consumer, and if so, the extent of that negotiation;

(f) whether, as a result of conduct engaged in by the supplier, the consumer was required to do anything that was not reasonably necessary for the legitimate interests of the supplier;

(g) the extent to which any documents relating to the transaction or agreement satisfied the requirements of section 22;

(h) whether the consumer knew or ought reasonably to have known of the existence and extent of any particular provision of the agreement that is alleged to have been unfair, unreasonable or unjust, having regard to any-

(i) custom of trade; and

(ii) any previous dealings between the parties;

(i) the amount for which, and circumstances under which, the consumer could have acquired identical or equivalent goods or services from a different supplier; and

(j) in the case of supply of goods, whether the goods were manufactured, processed or adapted to the special order of the consumer." Also see Sharrock Business Transactions Law 599.

Section 40 CPA.

Section 41 CPA.

Section 48(1)(a)(i) CPA.

Section 48(1)(b) CPA. 
circumstances. ${ }^{65}$ This list is not a comprehensive list and the court has wide powers and discretion. ${ }^{66}$ The powers in section 52(2) authorise a court to consider any information or circumstances it considers relevant. ${ }^{67}$ Many of the words and phrases used in section 52(2) are not defined, and courts will have to interpret these words and phrases to effect the aims, purposes and policies of the CPA. ${ }^{68}$

\subsection{Concluding remarks on parol evidence in the CPA}

There is no doubt the CPA has the objective, aim and purpose to protect the consumer and give effect to consumer rights in general. It improves the overall position of the consumer and the provisions discussed above are steps in the right direction, which should apply to all consumer agreements. The exclusion of the parol evidence rule should ideally be extended to fulfil the aims and objectives of the CPA. To date, no case law dealing expressly with the parol evidence rule under the CPA could be found.

\section{Parol evidence in the UK under the CRA}

\subsection{Introduction and background}

The parol evidence rule normally applies in agreements under the common law in the UK. ${ }^{69}$ There are exceptions to the parol evidence rule, mainly when it is evident that the parties did not intend the written contract to record the entire agreement. ${ }^{70}$ Therefore the ambit of the rule is limited until it is proven that the written contract was intended to form the only and whole agreement between the parties. ${ }^{71}$ The Law Commission stated this point of view in their 1986 Report on the rule..$^{72}$ This has also been confirmed by courts. $^{73}$

The only exception to this rule is that parol evidence is allowed where documents have to be connected to each other, or where there is an implied

\footnotetext{
65 Tennant and Mbele 2013 De Rebus 36.

$66 \quad$ Sharrock Business Transactions Law 599.

67 Bradfield Christie's Law of Contract 25.

68 Bradfield Christie's Law of Contract 25-26.

69 Jacobs v Batavia and General Plantations Trust [1924] 2 Ch 329; Adams v British Airways plc [1995] IRLR 574 para 21; Beatson, Burrows and Cartwright Anson's Law of Contract 146-148; Beale et al Chitty on Contracts Vol I 13-99 - 13-102.

$70 \quad$ Gillespie Bros and Co v Cheney, Eggar and Co [1896] 2 QB 5962.

71 Beale et al Chitty on Contracts Vol I 13-103; Beatson, Burrows and Cartwright Anson's Law of Contract 147.

72 Beale et al Chitty on Contracts Vol I 13-102; Beatson, Burrows and Cartwright Anson's Law of Contract 147-148; Law Commission Report: Law of Contract Parol Evidence 27.

73 See Yani Haryanto v ED and F Man (Sugar) Ltd [1986] 2 Lloyd's Rep 44; Rosseel NV v Oriental Commercial Shipping Co (UK) Ltd [1991] 2 Lloyd's Rep 625, 628.
} 
or express reference to that other document or documents in the contract. ${ }^{74}$ The inclusion of an "entire agreement" clause ${ }^{75}$ will not necessarily exclude parol evidence. ${ }^{76}$

\subsection{Parol evidence under the CRA}

The aim of the CRA in the preamble of the Act is:

to amend the law relating to the rights of consumers and protection of their interests; to make provision about investigatory powers for enforcing the regulation of traders; to make provision about private actions in competition law and the Competition Appeal Tribunal; and for connected purposes. ${ }^{77}$

The role of the CRA is to bring about reform in the field of consumer law in the UK. It seeks to clarify and modernise consumer law ${ }^{78}$ and to reconcile UK consumer law with that of the European Union (EU)..$^{79}$

The CRA does not expressly refer to parol evidence, its application or exclusion in consumer agreements. However, the following sections are relevant where the rule is excluded by implication:

74

75

Beale et al Chitty on Contracts Vol / 13-105 - 13-106.

These clauses are normally found in standard-term contracts, for instance standard consumer agreements. The purpose of these clauses is to exclude all statements or representations not included in the written agreement.

Beale et al Chitty on Contracts Vol / 13-107. The most likely reason is that the whole purpose of such a clause is to exclude statements or representations other than those in the written agreement, which could of course seriously disadvantage the other party. For a general discussion of the parol evidence rule and its application in the UK, see Beale Beale et al Chitty on Contracts Vol I 13-108 - 13-136.

Preamble of the Consumer Rights Act, 2015 (the CRA) ch 15. Chitty highlights four strategies of the CRA namely; implementation of the Unfair Terms in Consumer Contracts Regulations, 1999 the amendment of the Unfair Contract Terms Act, 1977, the wide application of Part 1 of the CRA, and the extension of enforcement measures. Beale et al Chitty on Contracts Vol II 38-341, also see 38-348 - 38-350. Devenney J 2018 JBL 485, 490.

The UK left the European Union (Brexit) without a negotiated deal on 31 January 2020 , and this, in the long term could potentially have an impact on the UK's consumer protection law regime. There was a transition period until 31 December 2020. However, at present Brexit should have a minimal impact on UK consumer protection law unless amended by Parliament in the UK in future; see Wessing 2020 https://www.lexology.com/library/detail.aspx?g=35bf694f-c5cb-415d-bd01-

54e3ef21a9f7; Which? Editorial Team 2021 https://www.which.co.uk/consumerrights/advice/how-will-brexit-affect-my-consumer-rights\#how-will-brexit-change-ourconsumer-rights. For an analysis of the legal implications of Brexit see Gee G, Rubini $\mathrm{L}$ and Trybus M Date Unknown https://www.birmingham.ac.uk/Documents/collegeartslaw/law/iel/leaving-EU-legal-impact-brexit-gee-rubini-trybus.pdf especially 4751; for more detail on the inclusion of EU consumer rights in the CRA see Giliker 2017 LS 78-102. For guidance on how consumer protection law is enforced after a 'no deal' exit from the EU see CMA 2019 https://assets.publishing. service.gov.uk/government/uploads/system/uploads/attachment_data/file/786749/E U_Exit_Guidance_Document_for_No_Deal_final.pdf 24-27. 
- When section 11(1) and 11(4), 80 in respect of goods, are analysed, it is clear the section provides that consumer contracts include precontractual information ${ }^{81}$ where the information relates to the main characteristics of the goods in question. ${ }^{82}$ Pre-contractual information includes but is not limited to presentations, communications, correspondence, and promotional material provided by the trader. ${ }^{83}$ This information will be regarded as a term or terms in the contract.

- Section $12^{84}$ provides that other information not included in the contract, in other words, information not related to the main characteristics of the goods, will also be included in the contract. ${ }^{85}$

- Section $36^{86}$ of the CRA provides that information provided on the main characteristics of digital content is included in a digital content

$80 \quad$ "11. Goods to be as described

(1) Every contract to supply goods by description is to be treated as including a term that the goods will match the description.

(4) Any information that is provided by the trader about the goods and is information mentioned in paragraph (a) of Schedule 1 or 2 to the Consumer Contracts (Information, Cancellation and Additional Charges) Regulations 2013 (SI 2013/3134) (main characteristics of goods) is to be treated as included as a term of the contract." Consumer Contracts Regulations, 2013 (SI 2013 No 3134), this includes most written and oral representations, notices, and advertisements; Beatson, Burrows and Cartwright Anson's Law of Contract 144-145. Explanatory Notes on the Consumer Rights Act, 201523. For instance, on a notice board, in advertisements, or notices. Also see Beatson, Burrows and Cartwright Anson's Law of Contract 144-145.

"12. Other pre-contract information included in contract

(1) This section applies to any contract to supply goods.

(2) Where regulation 9,10 or 13 of the Consumer Contracts (Information, Cancellation and Additional Charges) Regulations 2013 (SI 2013/3134) required the trader to provide information to the consumer before the contract became binding, any of that information that was provided by the trader other than information about the goods and mentioned in paragraph (a) of Schedule 1 or 2 to the Regulations (main characteristics of goods) is to be treated as included as a term of the contract." Explanatory Notes on the Consumer Rights Act, 2015 23-24.

$86 \quad$ "36. Digital content to be as described

(1) Every contract to supply digital content is to be treated as including a term that the digital content will match any description of it given by the trader to the consumer. (2) Where the consumer examines a trial version before the contract is made, it is not sufficient that the digital content matches (or is better than) the trial version if the digital content does not also match any description of it given by the trader to the consumer.

(3) Any information that is provided by the trader about the digital content that is information mentioned in paragraph (a), (j) or (k) of Schedule 1 or paragraph (a), (v) or $(w)$ of Schedule 2 (main characteristics, functionality and compatibility) to the Consumer Contracts (Information, Cancellation and Additional Charges) Regulations 2013 (SI 2013/3134) is to be treated as included as a term of the contract.

(4) A change to any of that information, made before entering into the contract or later, is not effective unless expressly agreed between the consumer and the trader. 
contract, ${ }^{87}$ and section $37^{88}$ deals with other information (not related to the main characteristics of the digital content) that will also form part of the agreement. ${ }^{89}$

- Section $50^{90}$ deals with information on the trader and the service provided to a consumer. The section provides that a trader should comply with the information he provided to the consumer, whether such information was provided verbally or in writing, where the consumer took this information into consideration to make a decision on the service, and whether to enter into the agreement or not.

\subsection{Concluding remarks on parol evidence in the CRA}

These exclusions of the parol evidence rule in the CRA, albeit by implication, demonstrate the trend in international jurisdictions to

(5) See section 42 for a consumer's rights if the trader is in breach of a term that this section requires to be treated as included in a contract."

Explanatory Notes on the Consumer Rights Act, 2015 44-45.

"37. Other pre-contract information included in contract

(1) This section applies to any contract to supply digital content.

(2) Where regulation 9, 10 or 13 of the Consumer Contracts (Information, Cancellation and Additional Charges) Regulations 2013 (SI 2013/3134) required the trader to provide information to the consumer before the contract became binding, any of that information that was provided by the trader other than information about the digital content and mentioned in paragraph (a), (j) or (k) of Schedule 1 or paragraph (a), (v) or (w) of Schedule 2 to the Regulations (main characteristics, functionality and compatibility) is to be treated as included as a term of the contract." Consumer Contracts Regulations, 2013 (SI 2013 No 3134), this includes most written and oral representations, notices, and advertisements; Beatson, Burrows and Cartwright Anson's Law of Contract 144-145; Explanatory Notes on the Consumer Rights Act, 201545.

$90 \quad$ "50. Information about the trader or service to be binding

(1) Every contract to supply a service is to be treated as including as a term of the contract anything that is said or written to the consumer, by or on behalf of the trader, about the trader or the service, if - (a) it is taken into account by the consumer when deciding to enter into the contract, or (b) it is taken into account by the consumer when making any decision about the service after entering into the contract.

(2) Anything taken into account by the consumer as mentioned in subsection (1)(a) or (b) is subject to- (a) anything that qualified it and was said or written to the consumer by the trader on the same occasion, and (b) any change to it that has been expressly agreed between the consumer and the trader (before entering into the contract or later).

(3) Without prejudice to subsection (1), any information provided by the trader in accordance with regulation 9, 10 or 13 of the Consumer Contracts (Information, Cancellation and Additional Charges) Regulations 2013 (SI 2013/3134) is to be treated as included as a term of the contract.

(4) A change to any of the information mentioned in subsection (3), made before entering into the contract or later, is not effective unless expressly agreed between the consumer and the trader.

(5) See section 54 for a consumer's rights if the trader is in breach of a term that this section requires to be treated as included in a contract." 
compensate the consumer who is in an inferior bargaining position by allowing extrinsic evidence in prescribed circumstances.

\section{Conclusion}

The parol evidence rule has been the subject of intense debate and conflicting opinions amongst scholars, judges and practitioners. When the development of the rule is traced, it is clear there is a definite movement in common-law cases, although conservatively and cautiously, to limit or exclude the rule in specific circumstances where it would ensure a just and fair result.

Standard-form contracts limit and restrict the consumer's freedom of contract, and therefore the maxim pacta servanda sunt should also be restricted in these contracts, as freedom of contract and pacta servanda sunt are mutually inclusive. Therefore, to compensate the consumer for his or her lack of bargaining power and resultant limited freedom of contract, parol evidence should be allowed in consumer agreements under the CPA to effect improved consumer protection. It has to be conceded that the limited exclusion of the parol evidence rule in the CPA is a definite improvement on the situation before the commencement of CPA. The comparison to consumer legislation in the UK, as enriched by EU consumer law, demonstrates the tendency in foreign jurisdictions to restrict or abolish the parol evidence rule in prescribed circumstances in order to assist the consumer, who typically enters into these agreements and who is in an inferior bargaining position, to prove his claim.

The express exclusion of the parol evidence rule in all consumer agreements under the CPA would without doubt benefit consumers in South Africa and provide much-needed clarity on this contentious issue. If a consumer could rely on all evidence to prove his case, it would improve transparency in consumer contracts, as suppliers would be cautious in their marketing material, verbal communications and all related matters and communications. In addition, it would assist the vulnerable consumers provided for in section 3(1)(b). In practice, such an exclusion would clearly improve consumers' access to justice, ensure effective redress for consumers as envisaged in the preamble of the CPA, and contribute towards fairness in consumer transactions. 


\section{Bibliography}

\section{Literature}

Ahdieh 2006 Mich L Rev

Ahdieh RB "The Strategy of Boilerplate" 2006 Mich L Rev 1033-1073

Aronstam Consumer Protection

Aronstam P Consumer Protection, Freedom of Contract and the Law (Juta Cape Town 1979)

Barnard Influence of the Consumer Protection Act

Barnard J The Influence of the Consumer Protection Act 68 of 2008 on the Common Law of Sale (LLD-thesis University of Pretoria 2013)

Barnes 2007 Wash L Rev

Barnes WR "Toward a Fairer Model of Consumer Assent to Standard Form Contracts: In Defense of Restatement Subsection 211(3)" 2007 Wash L Rev 227-274

Beale et al Chitty on Contracts Vol I

Beale HG et al Chitty on Contracts - Volume I: General Principles $32^{\text {nd }}$ ed (Sweet and Maxwell London 2015)

Beale Chitty on Contracts Vol II

Beale HG et al Chitty on Contracts - Volume II: Specific Contracts $32^{\text {nd }}$ ed (Sweet and Maxwell London 2015)

Beatson, Burrows and Cartwright Anson's Law of Contract

Beatson J, Burrows A and Cartwright J Anson's Law of Contract $30^{\text {th }}$ ed (Oxford University Press Oxford 2016)

Bekker Ekstrinsieke Getuienis-Reël

Bekker PM Die Ekstrinsieke Getuienis-Reël in die Suid-Afrikaanse Kontraktereg (LLD-thesis University of South Africa 2009)

Bekker 2013 Litnet Akademies

Bekker T "Die Herklassifisering van die Ekstrinsieke Getuienis-Reël en die Verdere Ontwikkeling van die Integrasiereël in die Suid-Afrikaanse Kontraktereg" 2013 Litnet Akademies 108-175

Bekker 2014 PELJ

Bekker T "Die Moontlike Regshervorming van die Integrasiereël in die SuidAfrikaanse Kontraktereg deur middel van die Leerstuk van Rektifikasie" 2014 PELJ 1138-1165 
Bhana Constitutionalising Contract Law

Bhana D Constitutionalising Contract Law: Ideology, Judicial Method and Contractual Autonomy (PhD-thesis University of the Witwatersrand 2013)

Bradfield Christie's Law of Contract

Bradfield GB Christie's Law of Contract in South Africa $7^{\text {th }}$ ed (LexisNexis Durban 2016)

Cockrell 1992 SALJ

Cockrell A "Substance and Form in the South African Law of Contract" 1992 SALJ 40-63

Cornelius 2009 TSAR

Cornelius S "Background Circumstances, Surrounding Circumstances and the Interpretation of Contracts" 2009 TSAR 767-775

Devenney $2018 \mathrm{JBL}$

Devenney $\mathrm{J}$ "The Legacy of the Cameron-Clegg Coalition Programme of Reform of the Law on the Supply of Goods, Digital Content and Services to Consumers" 2018 JBL 485-511

De Wet and Van Wyk Suid-Afrikaanse Kontraktereg en Handelsreg

De Wet JC and Van Wyk AH Die Suid-Afrikaanse Kontraktereg en Handelsreg - Volume $15^{\text {th }}$ ed (Butterworths Durban 1992)

Du Bois et al Wille's Principles of South African Law

Du Bois $\mathrm{F}$ et al Wille's Principles of South African Law $9^{\text {th }}$ ed (Juta Cape Town 2007)

Eiselen 1989 THRHR

Eiselen GTS "Kontrakteervryheid, Kontraktuele Geregtigheid en die Ekonomiese Liberalisme" 1989 THRHR 516-539

Giliker 2017 LS

Giliker P "The Consumer Rights Act 2015 - A Bastion of European Consumer Rights?" 2017 Legal Studies 78-102

Gluck 1979 ICLQ

Gluck G "Standard Form Contracts: The Contract Theory Reconsidered" 1979 ICLQ 72-90

Harland $1991 \mathrm{JILI}$

Harland D "Implementing the Principles of the United Nations Guidelines for Consumer Protection" 1991 JILI 189-245 
Hiemstra and Gonin Drietalige Regswoordeboek

Hiemstra VG and Gonin HL Drietalige Regswoordeboek $3^{\text {rd }}$ ed (Juta Cape Town 2008)

Hutchison and Pretorius Law of Contract

Hutchison D and Pretorius CJ (eds) The Law of Contract in South Africa $2^{\text {nd }}$ ed (Oxford University Press Cape Town 2014)

Kessler 1943 Colum L Rev

Kessler F "Contracts of Adhesion: Some Thoughts about Freedom of Contract" 1943 Colum L Rev 629-642

Klare 1998 SAJHR

Klare KE "Legal Culture and Transformative Constitutionalism" 1998 SAJHR 146-188

Langa 2006 Stell $L R$

Langa P "Transformative Constitutionalism" 2006 Stell LR 351-360

Law Commission Report: Law of Contract

The Law Commission Report: Law of Contract - The Parol Evidence Rule (Her Majesty's Stationary Office London 1986)

Levenstein and Barnett 2010 Without Prejudice

Levenstein E and Barnett L "Rest in Peace - The Parol Evidence Rule" 2010 December Without Prejudice 30-31

Moseneke 2009 Stell LR

Moseneke D "Transformative Consitutionalism: Its Implications for the Law of Contract" 2009 Stell LR 3-13

Pretorius 2003 THRHR

Pretorius CJ "Individualism, Collectivism and the Limits of Good Faith" 2003 THRHR 638-645

Rakoff 1983 Harv L Rev

Rakoff T "Contracts of Adhesion: An Essay in Reconstruction" 1983 Harv L Rev 1173-1284

Sharrock Business Transactions Law

Sharrock R Business Transactions Law $9^{\text {th }}$ ed (Juta Cape Town 2016)

Stoop Concept "Fairness" in the Regulation of Contracts

Stoop P The Concept "Fairness" in the Regulation of Contracts under the Consumer Protection Act 68 of 2008 (LLD-thesis University of South Africa 2012) 
Tennant and Mbele 2013 De Rebus

Tenant $S$ and Mbele $V$ "The Consumer Protection Act and Five Common Law Principles" 2013 De Rebus 36-38

Tladi 2002 De Jure

Tladi DD "Breathing Constitutional Values into the Law of Contract: Freedom of Contract and the Constitution" 2002 De Jure 306-317

Van Eeden and Barnard Consumer Protection Law

Van Eeden E and Barnard J Consumer Protection Law in South Africa $2^{\text {nd }}$ ed (LexisNexis Durban 2017)

Van der Walt 2005 TSAR

Van der Walt AJ "Transformative Constitutionalism and the Development of South African Property Law (Part 1)" 2005 TSAR 655-698

Van der Walt 2006 TSAR

Van der Walt AJ "Transformative Constitutionalism and the Development of South African Property Law (Part 2)" 2006 TSAR 1-31

Van Huyssteen, Lubbe and Reinecke Contract

Van Huyssteen LF, Lubbe GF and Reinecke MFB Contract: General Principles $5^{\text {th }}$ ed (Juta Cape Town 2016)

Van Jaarsveld and Oosthuizen Suid-Afrikaanse Handelsreg

Van Jaarsveld SR and Oosthuizen T (eds) Suid-Afrikaanse Handelsreg Volume $/ 3^{\text {th }}$ ed (Lex Patria Johannesburg 1988)

Visser 1984 SALJ

Visser C "The Principle Pacta Servanda Sunt in Roman and Roman-Dutch Law, with Specific Reference to Contracts in Restraint of Trade" 1984 SALJ 641-655

\section{Case law}

Adams v British Airways plc [1995] IRLR 574

Akasia Road Surfacing v Shoredits Holdings 20023 SA 346 (SCA)

Avis v Verseput 1943 AD 331

Bothma-Batho Transport (Edms) Bpk v S Bothma \& Seun Transport (Edms) Bpk 20142 SA 494 (SCA)

Coopers and Lybrand $v$ Bryant 19953 SA 761 (A)

Delmas Milling Co Ltd $v$ du Plessis 19553 SA 447 (A)

Du Plessis v Nel 19521 SA 513 (A) 
Everfresh Market Virginia (Pty) Ltd v Shoprite Checkers (Pty) Ltd 20121 SA 25 (CC)

Gillespie Bros and Co v Cheney, Eggar and Co [1896] 2 QB 59

Harlin Properties v Los Angeles Hotel 19623 SA 143 (A)

Imperial Group (Pty) Ltd t/a Cargo Motors Klerksdorp v Dipico 2016 ZANCHC 1 (1 April 2016)

Jacobs v Batavia and General Plantations Trust [1924] 2 Ch 329

Johnson v Leal 19803 SA 927 (A)

KPMG Chartered Accountants (SA) v Securefin Ltd 20092 All SA 523 (SCA)

Linstrom $v$ Venter 19571 SA 125 (SWA)

Lowrey $v$ Steedman 1914 AD 532

Meyer v Merchants Trust Ltd 1942 AD 244

National Board (Pretoria) (Pty) Ltd v Estate Swanepoel 19753 SA 16 (A)

Peter $v$ Thomas (1908) EDC 140

Phumelela Gaming and Leisure Limited v Gründlingh 20068 BCLR 883 (CC)

Printing and Numerical Registries Co v Sampson (1875) LR 19 Eq 462

Reilly v Seligson and Clare Ltd 19771 SA 626 (A)

Rosseel NV v Oriental Commercial Shipping Co (UK) Ltd [1991] 2 Lloyd's Rep 625

Strydom v Coach Motors 19754 SA 838 (T)

Union Government v Vianini Ferro-Concrete Pipes (Pty) Ltd 1941 AD 43

Venter v Birchholtz 19721 SA $276(\mathrm{~A})$

Wells v South African Alumenite Co 1927 AD 69

Western Bank Ltd v Sparta Construction Co 19751 All SA 224 (W)

Yani Haryanto v ED and F Man (Sugar) Ltd [1986] 2 Lloyd's Rep 44

\section{Legislation}

Constitution of the Republic of South Africa, 1996 
Consumer Protection Act 68 of 2008

Consumer Rights Act, 2015

\section{Government publications}

Consumer Contracts (Information, Cancellation and Additional Charges) Regulations, 2013 (SI 2013/3134) (UK)

Consumer Protection Bill [B19-2008]

Explanatory Notes on the Consumer Rights Act, 2015 (UK)

Gen N 1957 in GG 26774 of 9 September 2004 (Draft Green Paper on the Consumer Policy Framework)

Unfair Contract Terms Act, 1977

Unfair Terms in Consumer Contracts Regulations, 1999

\section{Internet sources}

CMA 2019 https://assets.publishing.service.gov.uk/government/uploads/ system/uploads/attachment_data/file/786749/EU_Exit_Guidance_Docume nt_for_No_Deal_final.pdf

Competition and Markets Authority 2019 Guidance on the Functions of the CMA after a "No Deal" Exit from the EU https://assets. publishing.service.gov.uk/government/uploads/system/uploads/attachment _data/file/786749/EU_Exit_Guidance_Document_for_No_Deal_final.pdf accessed 25 January 2021

Gabel 2020 https://www.britannica.com/topic/European-Union

Gabel MJ 2020 European Union https://www.britannica.com/topic/ European-Union accessed 25 January 2021

Gee $G$, Rubini $L$ and Trybus $M$ Date Unknown https://www.birmingham.ac.uk/Documents/college-artslaw/law/iel/leavingEU-legal-impact-brexit-gee-rubini-trybus.pdf

Gee G, Rubini L and Trybus M (eds) Date Unknown Leaving the EU? The Legal Impact of "Brexit" on the United Kingdom https://www.birmingham.ac.uk/Documents/college-artslaw/law/iel/leavingEU-legal-impact-brexit-gee-rubini-trybus.pdf accessed 25 January 2021

Merriam Webster Date Unknown https://www.merriamwebster.com/dictionary/laissez-faire

Merriam Webster Date Unknown Laissez-faire https://www.merriamwebster.com/dictionary/laissez-faire accessed 11 January 2021 
UNCTAD 2016 https://unctad.org/en/PublicationsLibrary/ditccplpmisc 2016d1_en.pdf

United Nations Conference on Trade and Development 2016 United Nations Guidelines for Consumer Protection https:/unctad.org/en/ PublicationsLibrary/ditccplpmisc2016d1_en.pdf accessed 25 January 2021

Wessing 2020 https://www.lexology.com/library/detail.aspx?g=35bf694fc5cb-415d-bd01-54e3ef21a9f7

Wessing T 2020 Developments in UK and EU Consumer Protection in 2020 https://www.lexology.com/library/detail.aspx?g=35bf694f-c5cb-415d-bd0154e3ef21a9f7 accessed 11 January 2021

Which? Editorial Team 2021 https://www.which.co.uk/consumerrights/advice/how-will-brexit-affect-my-consumer-rights\#how-will-brexitchange-our-consumer-rights

Which? Editorial Team 2021 How will Brexit Affect my Consumer Rights? https://www.which.co.uk/consumer-rights/advice/how-will-brexit-affect-myconsumer-rights\#how-will-brexit-change-our-consumer-rights accessed 11 April 2021

\section{List of Abbreviations}

\section{CMA}

Colum L Rev

CPA

CRA

EU

Harv L Rev

ICLQ

$J B L$

JILI

LS

Mich L Rev

PELJ

SAJHR

SALJ

Stell LR

THRHR

TSAR

UK
Competition and Markets Authority

Columbia Law Review

Consumer Protection Act

Consumer Rights Act

European Union

Harvard Law Review

International and Comparative Law Quarterly

Journal of Business Law

Journal of the Indian Law Institute

Legal Studies

Michigan Law Review

Potchefstroom Electronic Law Journal

South African Journal on Human Rights

South African Law Journal

Stellenbosch Law Review

Tydskrif vir Hedendaagse Romeins-

Hollandse Reg

Tydskrif vir die Suid-Afrikaanse Reg

United Kingdom 
UNCTAD

Wash L Rev
United Nations Conference on Trade and Development

Washington Law Review 